\title{
O SUPERENDIVIDAMENTO DO CONSUMIDOR NO BRASIL: UM DEBATE NECESSÁRIO ENTRE O DIREITO E A ECONOMIA NO SÉCULO XXI
}

\section{OVERINDEBTEDNESS CONSUMER IN BRAZIL: A NECESSARY LAW AND ECONOMICS DEBATE IN THE XXI CENTURY}

\author{
${ }^{1}$ Ana Elizabeth Neirao Reymao \\ ${ }^{2}$ Felipe Guimarães de Oliveira
}

\section{RESUMO}

$\mathrm{O}$ artigo investiga a interface entre o Direito e a Economia no que dista ao tema do superendividamento do consumidor de crédito no Brasil no século XXI. Verifica-se que o novo desenvolvimentismo envolveu uma política de estímulo ao crescimento que levou a uma expansão do crédito que favoreceu a majoração dos índices de endividamento dos brasileiros nos últimos anos. A alternativa factível para a prevenção e tratamento do problema emerge do Projeto de Lei $n^{\circ}$ 283/2012, cujo estudo e crítica são abordados no presente trabalho.

Palavras-chave: Superendividamento, Consumidor, Novo desenvolvimentismo, Economia, Direito

\begin{abstract}
The article investigates the interface between law and economics in which is distant to the credit consumer overindebtedness theme in Brazil in the XXI century. It appears that the new developmentalism involved stimulating a policy of growth that led to an expansion of credit which favored the increase of the Brazilian debt ratios in recent years. A feasible alternative for the prevention and treatment of problem emerges from Bill No. 283/2012, the study and criticism are addressed in this work.
\end{abstract}

Keywords: Overindebtedness, Consumer, "new developmentalism”, Economics, Law

\footnotetext{
${ }^{1}$ Doutora em Ciências Sociais pela Universidade de Brasília - UnB, Distrito Federal (Brasil). Professora de Economia e Estatística pela Universidade Federal do Pará - UFPA, Pará (Brasil). E-mail: bethrey@uol.com.br

${ }^{2}$ Mestrando em em Direito, Políticas Públicas e Desenvolvimento Regional pelo Centro Universitário do Estado do Pará - CESUPA, Pará (Brasil). Advogado em Gonçalves, Amoras, Verbicaro e Lima - Advogados Associados GAVL, Pará (Brasil). E-mail: fguima.oliveira@ hotmail.com
} 


\section{Introdução}

A discussão da viabilidade de uma tutela jurídica que seja capaz de prevenir e tratar o superendividamento no Brasil é tema desse artigo, que argumenta que alguns pilares do novo desenvolvimentismo foram fundamentais para favorecer o problema no país. O objetivo do texto é mostrar que o superendividamento é um dos efeitos negativos dessa política sobre as famílias brasileiras e propor um tratamento jurídico para os consumidores superendividados no país.

As mudanças na estrutura social e econômica brasileira, com a redução das desigualdades sociais, chegada de novos consumidores ao mercado, abertura de novas empresas e aumento da formalização de negócios apontavam perspectivas bastante promissoras para a economia brasileira no início do século XXI. Esse cenário favorável de crescimento econômico levou o Brasil a ser incluído nos BRICS, grupo político também formado por Rússia, Índia, China e, posteriormente, África do Sul, que compartilhavam índices de desenvolvimento e situação econômica parecidas.

Alguns autores afirmavam tratar-se de uma nova fase da economia brasileira, período que viria a se constituir um rompimento com as políticas liberais defendidas pelo Consenso do Washington no país: Barbosa (2013), Belluzzo (2013) e Sader (2013), entre outros. Assim, o ano de 2003 foi festejado como a introdução de uma nova dinâmica que envolveria decisões de políticas públicas em favor do estímulo ao crescimento, acompanhadas de uma forte política distributiva. As gestões dos presidentes Lula e Dilma trouxeram programas de governo "novo desenvolvimentistas", termo surgido em 2003 quando os economistas Yoshiaki Nakano e Bresser-Pereira realizavam estudos conjuntos e críticos à política econômica brasileira dos anos 1990, apoiada no Consenso de Washington e nas teses ortodoxas (REYMÃO e MIRANDA, 2014).

O Brasil apresentava demanda crescente por investimentos, produtos e serviços, sustentado por um grande mercado interno e fortalecido pela maior oferta de crédito, mais emprego e renda. Porém, desde 2013 esse modelo econômico tem sido duramente contestado e, por vezes, inviabilizado por desequilíbrios decorrentes de opções de políticas que estimularam o consumo sem criar um ambiente para estimular a competitividade da economia e sem promover um crescimento econômico que viabilizasse o aumento da arrecadação para financiar as elevadas despesas da política novo desenvolvimentista. A piora da situação econômica e política do país começava a ficar mais clara e diversos segmentos sociais foram às ruas protestar. Interrompia-se o ciclo expansionista favorecido pela conjuntura econômica e 
marcado por medidas de política econômica que alargaram o mercado de crédito no país e estimularam o consumo, promoveram a inclusão social e econômica de milhões de brasileiros, combinando crescimento econômico com a redução das desigualdades no país.

O modelo que buscou a promoção do desenvolvimento econômico com inclusão social baseado em uma estratégia de crescimento apoiada no mercado interno e no aumento do crédito revelou suas fragilidades e trouxe novos desafios e dificuldades, com cerca de $40 \%$ inadimplentes na população brasileira com 18 anos ou mais em 2014, segundo dados da Serasa Experian.

$\mathrm{Na}$ discussão desse efeito social negativo do modelo sobre as famílias endividadas, perversos notadamente sobre as de menor poder aquisitivo, é que se impõe a necessidade de estudo e análise do possível tratamento jurídico de uma categoria de consumidores superendividados no Brasil, cabendo também investigar como o ordenamento pátrio tem trabalhado o tema na esfera consumerista.

Em uma pesquisa bibliográfica e documental, revisitando a literatura do tema e analisando os documentos oficiais acerca da política econômica do período novo desenvolvimentista, o artigo discute a problemática ora apresentada. Foram coletados dados no Sistema Gerenciador de Séries Temporais do Banco Central (Bacen) e no banco de dados IPEADATA para fundamentar as análises aqui desenvolvidas. O tex to está estruturado em cinco partes, incluindo essa introdução e as considerações finais. Nas seções seguintes, o artigo apresenta o novo desenvolvimentismo como crítica à política econômica neoliberal e alguns elementos de sua política macroeconômica, base das condições que favoreceram a expansão do crédito no país. Posteriormente, analisa-se a política expansionista adotada após a crise internacional de 2008, que comprometeu os efeitos positivos do modelo até então evidentes, levando o governo a adotar uma política econômica que intensificou o superendividamento. $\mathrm{Na}$ seção 4, discute-se o direito do consumidor e se há perspectivas factíveis de prevenção e tratamento do superendividamento no Brasil. As considerações finais apresentam algumas conclusões desse estudo.

\section{O novo desenvolvimentismo e alguns elementos de sua política macroeconômica que favoreceram a expansão do crédito}

O novo desenvolvimentismo é uma expressão que autores como Barbosa (2013), Belluzzo (2013), Sader (2013) e Bresser-Pereira (2006) adotam para defender a ideia de que a política econômica dos presidentes Lula e Dilma resulta na adoção de um novo modelo de 
desenvolvimento, caracterizado por uma política de estímulo ao crescimento acompanhada de uma política distributiva, o que importava uma nova dinâmica para a economia brasileira após 2003.

O neoliberalismo tinha fracassado, não apenas em superar a "crise de modelo", como ainda piorou as condições econômicas e sociais do país: em 1998, a taxa de crescimento do produto interno bruto (PIB) era apenas de $0,1 \%$ aa, tendo o PIB per capita crescido apenas 1\% entre 1992 e 1994 (Itamar Franco) e de 1995 a 2002 (Fernando Henrique Cardoso FHC), como evidenciam os dados do Bacen. As medidas propagadas pelo Consenso de Washington e pela ortodoxia convencional e implantadas nos governos Collor e FHC a partir dos anos 1990, como disciplina fiscal, priorização dos gastos públicos, reforma tributária, liberalização financeira, cambial e comercial, investimento direto estrangeiro, privatização e desregulação, trouxeram a estabilidade monetária, é verdade, mas também uma aguda recessão e agravamento de problemas sociais no país, quadro que só mudou após o primeiro governo novo desenvolvimentista, como lembra Sader (2013, p. 138):

Depois da estabilidade monetária, o impulso de apoio ao programa neoliberal terminou e, após três crises, sempre com empréstimos e acordos de ajuste do FMI, a economia brasileira entrou em profunda e prolongada recessão, da qual só sairia no governo Lula.

O baixo desempenho do PIB, que só se recuperou nos anos seguintes, com a retomada do crescimento no governo Lula (gráfico 1), foi resultado das medidas impostas à economia brasileira nos acordos de ajuste do Fundo Monetário Internacional (FMI). Essas propostas, baseadas no Consenso de Washington, pautam-se em dois objetivos ${ }^{1}$ : redução do tamanho do Estado e abertura econômica (BATISTA, 1994), que fizeram a economia brasileira mergulhar em profunda e prolongada recessão. A nova trajetória de aumento do PIB só ocorreu com o novo desenvolvimentismo, como se vê no gráfico 1. Do Plano Real aos governos FHC (19942002), o PIB cresceu a 2,7\% a.a., enquanto que nos governos Lula (2003-2010), o crescimento foi muito superior, apesar da crise internacional de 2008-2009: 4,1\% a. $\mathrm{a}^{2}$.

\footnotetext{
${ }^{1}$ Como mostra Batista (1994, p. 18): "As propostas do Consenso de Washington nas 10 áreas a que se dedicou convergem para dois objetivos básicos: por um lado, a drástica redução do Estado e a corrosão do conceito de Nação; por outro, o máximo de abertura à importação de bens e serviços e à entrada de capitais de risco. Tudo em nome de um grande princípio: o da soberania absoluta do mercado autorregulável nas relações econômicas tanto internas quanto externas".

${ }^{2} \mathrm{O}$ gráfico também evidencia, no entanto, que esse crescimento não se sustentou e a economia reduziu seu crescimento na primeira gestão da presidente Dilma Rousseff. Ainda assim, uma análise da variação real do PIB brasileiro entre os anos 1980 e os governos do presidente FHC (1981-2002) mostra que o aumento do PIB foi de $2,1 \%$ a.a., ficando ainda abaixo dos 12 anos do período novo desenvolvimentista que o sucedeu, pois entre 2003 e 2014 o crescimento foi de $3,2 \%$ a.a.
} 
A combinação de crescimento econômico com menor desigualdade do novo desenvolvimentismo visaria o cumprimento das funções alocativa, estabilizadora e distributiva $^{3}$ do Estado brasileiro, em consonância com o princípio constitucional da busca pelo pleno emprego, conforme Artigo 170 da Carta Magna de 1988.

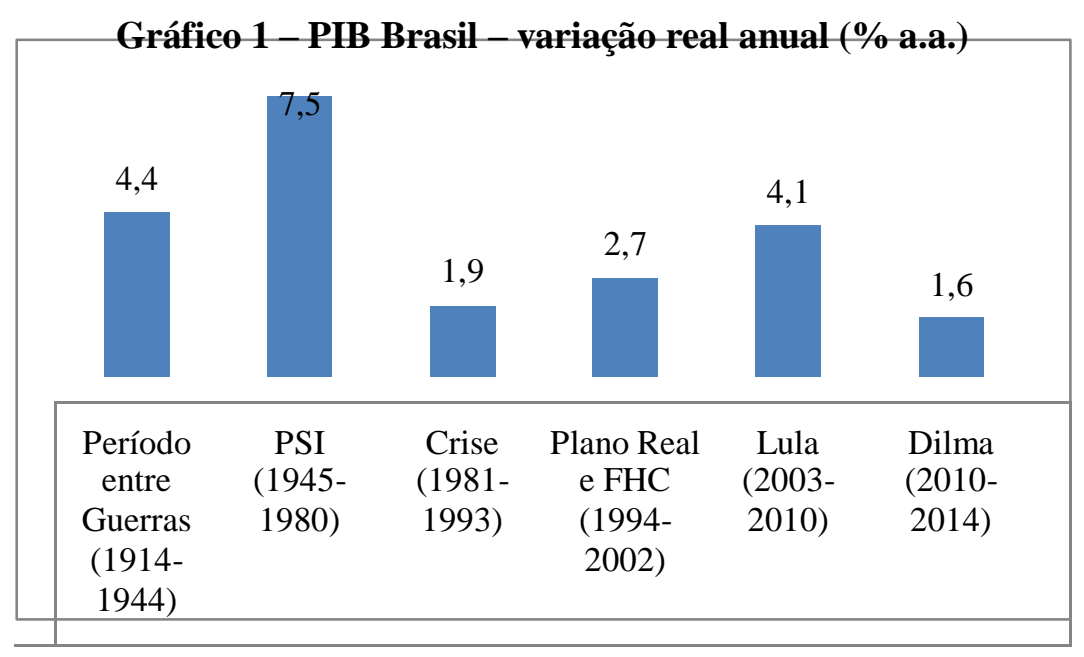

Fonte: Ipeadata

Como política econômica aplicada, os primeiros anos do novo desenvolvimentismo foram de um certo conservadorismo. O presidente Lula manteve o famoso tripé das políticas neoliberais composto por uma política monetária determinada pelas metas de inflação, câmbio flutuante e uma política fiscal visando manter um superávit primário que compensasse o déficit nominal das contas públicas (MORAIS e SAAD-FILHO, 2011).

O período 2003-2005 foi de ajuste macroeconômico e a redução da inflação e a diminuição do endividamento do setor público eram as prioridades do governo (BARBOSA, 2013). Na fase seguinte, de 2006 a 2008, a inflação estava sob controle e as políticas fiscal e monetária foram expansionistas. Na área monetária, a redução da taxa de juros Selic a partir de setembro de 2005 foi a principal medida. Entre setembro de 2005 (19,5\%) e abril de 2008 $(11,75 \%)$, foram sucessivas reduções ${ }^{4}$. Na área fiscal os resultados também foram favoráveis, com a redução da dívida líquida do setor público para 37,6\% do PIB no final de 2008 (contra

\footnotetext{
${ }^{3}$ Em The Theory of Public Finance (1959), obra clássica de Richard Abel Musgrave, o autor sintetiza o que é definido em muitas teorias sobre as atribuições econômicas básicas do Estado na economia: o exercício de três funções - alocativa (produção de bens), estabilizadora (minimização dos efeitos negativos da flutuação do ciclo econômico e da inflação) e distributiva (atenuar as desigualdades sociais e regionais). As análises de Reymão (2014) e Reymão e Miranda (2014) revelam problemas no cumprimento de tais funções.

${ }^{4} \mathrm{O}$ crescimento da produção agrícola brasileira, o aumento acelerado dos preços das commodities a partir de 2007 e a apreciação da taxa de câmbio (dólar a R \$1,77) ajudaram a controlar a inflação e criaram um ambiente favorável para essa mudança de postura do Banco Central, explicam seus Relatórios Anuais.
} 
47,8\% do início de 2006). Outra importante política expansionista dessa fase foi a de rendas, que teve como marca o aumento do valor real do salário mínimo (14\% em 2006 e mais de $54 \%$ entre 2003 e $2010^{5}$ ) e do número de famílias atendidas pelo Bolsa Família, o principal programa de combate à pobreza do governo federal, com reajuste do valor dos benefícios ${ }^{6}$. Em termos de infraestrutura, os investimentos também se elevaram, inicialmente com a reparação de rodovias (Operação Tapa-Buracos de 2006) e com o Programa de Aceleração do Crescimento (PAC) ${ }^{7}$, lançado em 2007.

O resultado dessas políticas expansionistas foi um forte crescimento do PIB (de 4\%, em 2006 para 6,1\%, em 2007 e 5,1\% em 2008), com aumento da taxa média investimento (de $14,8 \%$ para $16,6 \%$ do PIB entre o primeiro trimestre de 2006 e o de 2008), do consumo das famílias (de 3,3\% para 3,45\% do PIB de 2006 a 2008), do investimento público e do investimento da Petrobras, além da elevação de lucros e salários e expansão no crédito, chegando a 40\% do PIB, em 2008 contra $28 \%$ em 2005 e 30,7\% em 2006.

Porém, se de um lado permitiram as melhoras distributivas, como o aumento do poder de compra do salário mínimo, a expansão dos salários reais, a redução da taxa de desemprego e a inclusão bancária ${ }^{8}$, por outro lado levaram um forte endividamento das famílias, além da elevação da taxa de inadimplência. No setor bancário, a taxa que mede os atrasos superiores a noventa dias foi de $5 \%$ em 2006, com crescimento de 0,8 p.p. em relação a 2005. Para as pessoas físicas, a inadimplência foi de 7,6\% em 2006 (aumento de 0,9 p.p.), enquanto que as pessoas jurídicas as taxa foi de 2,7\% (aumento de 0,7 p.p). A decomposição do spread bancário do Relatório de Economia Bancária e Crédito de 2007 mostra que houve um forte acréscimo do componente associado à inadimplência, que era $32 \%$ em 2003 e passou a mais de $37 \%$ em 2007.

\footnotetext{
${ }^{5}$ Um salário mínimo comprava 1,47 cesta básica em 2003 e 2,27 cestas em 2010, o que significa cerca de 54\% no aumento do poder de compra em relação à cesta básica. No início do governo Dilma, tem-se uma pequena retração em relação ao governo anterior: um salário mínimo comprava 2,09 cestas básicas no primeiro ano (2011) e 2,18 cestas no segundo ano (2012), tomando-se como referência os dados do IBGE.

${ }^{6}$ Lançado em 2003, o programa Bolsa Família atingiu sua meta inicial de atendimento, de cerca de 11 milhões de famílias beneficiárias em 2006. De 2012 a 2015, o número de famílias beneficiadas tem se mantido estável em torno de 14 milhões. Dados do Ministério do Desenvolvimento Social mostram que o valor médio do benefício aumentou de $\mathrm{R} \$ 72,33$ para $\mathrm{R} \$ 150,27$ em 2014 (quase 108\%), equivalendo um ganho real próximo a $26 \%$.

${ }^{7} \mathrm{O}$ PAC planejou uma série de investimentos prioritários em infraestrutura econômica e social visando elevar a taxa de investimento da economia e eliminar os principais gargalos do país. Além dos investimentos logísticos, destacavam a produção de energia, incluindo os da Petrobras na exploração e produção de petróleo na camada do pré-sal.

${ }^{8}$ Essa inclusão é evidenciada pelo aumento do número de pontos de atendimento de serviços bancários à população, do número de municípios atendidos, do uso de produtos e serviços financeiros por parte das pessoas e dos empreendimentos, da taxa de bancarização e de outros indicadores disponíveis nos Relatórios de Inclusão Financeira do Bacen.
} 


\section{A crise internacional e o novo desenvolvimentismo: como a política expansionista influenciou o endividamento das famílias brasileiras?}

O ciclo expansionista foi interrompido com a quebra do banco Lehman Brothers e a crise no mercado financeiro norte-americano em 2008, que resultaram em uma forte queda da oferta de crédito no país e um aumento das incertezas, especialmente sobre a solvência de grupos empresariais do setor exportador brasileiro, além de redução do poder de compra das famílias e queda do crescimento do consumo privado (SADER, 2013).

A resposta do governo à crise internacional veio na forma intensificação da política expansionista na área fiscal e monetária: redução da taxa Selic (que ficou em 8,75\% entre julho de 2009 e março de 2010), aumento do crédito do sistema financeiro (elevou-se de $41 \%$ para $45 \%$ do PIB entre 2008 e 2009), especialmente com o crescimento dos recursos direcionados (de cerca de $12 \%$ para 14,6\% do PIB), e alta participação dos bancos públicos no total de crédito concedido pelo sistema financeiro (elevou-se de 36,3\% em 2008 para 41,5\% em 2009), mostram Annibal et alli (2009). Apesar da queda das receitas do governo, a política de rendas foi mantida, com os reajustes do salário mínimo, aumento das transferências e elevação das despesas com a previdência social, o abono salarial e o seguro-desemprego. $\mathrm{O}$ aumento dos investimentos veio na forma de gastos com infraestrutura do PAC, sobretudo na área de transportes e logística, bem como no aumento do investimento da Petrobras na exploração e produção de petróleo. Veio também com o Programa Minha Casa Minha Vida $(\mathrm{PMCMV})^{9}$, que incentivou a construção civil e assumiu a maior parte de provisão habitacional de interesse social do país, visando às famílias de baixa renda. Além de reduzir o déficit habitacional no país, a lógica do PMCMV foi estimular o crescimento de um setor muito intensivo em trabalho e pouco intensivo em importações como instrumento de geração de emprego e renda (BARBOSA, 2013).

Além da injeção de liquidez e de aumento de investimentos, faziam parte do pacote de medidas anticíclicas um conjunto de desonerações tributárias para estimular o consumo e o investimento. Em fins de 2008, o governo reduziu as alíquotas do Imposto sobre Produtos Industrializados (IPI) para a compra de automóveis, cuja produção acumulava um elevado

\footnotetext{
${ }^{9}$ O PMCMV foi lançado em 2009 como parte das medidas anticíclicas do governo frente à crise econômica internacional, mas também se destaca pela proposta social e inovações na política habitacional brasileira. Em parceria com governos estaduais e municipais e com recursos do Orçamento Geral da União (OGU) e do Fundo de Garantia por Tempo de Serviço (FGTS), o governo passou a estimular a compra da unidade habitacional por meio de medidas como a redução da taxa de juros, a menor burocratização na compra e outros subsídios à população brasileira de baixa renda. O Ministério das Cidades é o gestor do programa, tendo a Caixa Econômica Federal (CAIXA) como o órgão que financia e averigua as obras, além de regular os gastos dos empreendimentos e intermediar os financiamentos à população (Medida Provisória 459/2009).
} 
estoque involuntário. Com esse incentivo, uma das principais modalidades de crédito livre a pessoas físicas que estava entre as mais afetadas pela crise, a de aquisição de bens-veículos, voltou a crescer. Posteriormente, essa redução do IPI foi também ampliada para outros bens de consumo duráveis como eletrodomésticos (linha branca) e material de construção, mostra o Relatório Anual do Bacen 2009.

O conjunto de ações do governo Lula resultou na recuperação da economia brasileira, com aumento do PIB de 7,53\% em 2010, contra uma queda de $-0,33 \%$ no ano anterior. $\mathrm{O}$ investimento se recuperou, mas o grande destaque foi para o consumo das famílias que contribuiu com 4,24\% no crescimento do PIB em 2010, contra 2,62\% em 2009, superando em mais de $60 \%$ a participação nesse ano.

Os períodos seguintes revelaram aceleração da inflação, piora do saldo comercial brasileiro e comprometimento da competitividade da economia brasileira, o que levou o a presidente Dilma, no início do segundo governo novo desenvolvimentista, a adotar algumas medidas de cunho restritivo, com contingenciamento de gastos públicos, arrefecendo os investimentos em infraestrutura do PAC, e elevação da taxa Selic. A política de rendas, no entanto, foi mantida, com novas elevações do salário-mínimo e a expansão da rede de proteção social e combate à pobreza.

Com uma taxa de juros tão elevada (12,5\% a.a. em julho de 2011), ainda que pequena perto dos níveis históricos, a entrada de recursos externos fez o câmbio apreciar a $\mathrm{R} \$ 1,56 / \mathrm{US} \$$ em fins do primeiro semestre desse ano. Nesse patamar tão baixo, comprometia a competitividade da economia brasileira e levou o governo a adotar outras medidas para conter a inflação: elevação dos depósitos compulsórios e dos requerimentos de capital dos bancos. Essa postura restritiva da política monetária visava conter a expansão do crédito em segmentos específicos, desestimulando contratações com prazos muito dilatados, por exemplo, nos financiamentos para aquisição de veículos. O crédito cresceu, mas a taxas menores ${ }^{10}$. Cresceu também a inadimplência no total do crédito do sistema financeiro e atingiu de 3,6\% em dezembro (havia caído de 4,3\% em 2009 para 3,2\% em 2010), revelam os dados dos Relatórios de Economia Bancária e Crédito do Bacen. Isso piorou as condições de acesso financiamentos, pois as instituições iniciaram um aumento gradativo da seletividade na oferta de crédito para as famílias, notadamente ao voltado à aquisição de veículos. Maiores pagamentos de entrada foram exigidos, o que implica uma redução da relação entre o valor do

\footnotetext{
${ }^{10} \mathrm{Em}$ 2011, as operações de crédito do sistema financeiro, incluídas as operações com recursos livres e direcionados, avançaram menos que no ano anterior, mas continuaram crescendo: $19 \%$ no ano, após elevações de 15,2\% em 2009 e 20,6\% em 2010. Porém, a relação crédito/Produto Interno Bruto (PIB) se elevou, alcançando 49\% em 2011, ante 43,7\% em 2009 e 45,2\% em 2010.
} 
financiamento e o valor do bem financiado (menor loan-to-value). As principais modalidades afetadas pela queda no ritmo de expansão do crédito foram os financiamentos de veículos e o crédito pessoal, que cresceram bem menos $(23,5 \%$ e $19,2 \%$ em 2011 , respectivamente, ante 49,1\% e 24,7\% em 2010). O crédito para habitação continuou crescendo a taxas elevadas, porém menores (44,5\% em 2011, após expansão de 45,2\% em 2009 e de 51,1\% em 2010).

O quadro acima descrito indica uma demanda mais moderada de recursos para investimentos e o consumo, que embora crescendo em ritmo mais lento, continuava em alta, apesar das medidas macroprudenciais e da elevação do imposto sobre operações financeiras (IOF) incidente sobre as operações de crédito pessoal, que elevaram as taxas de juro de mercado visando desacelerar o crescimento dos financiamentos ao consumo.

A queda do PIB de 7,53\% para 2,73\% em 2011 foi superior ao esperado pelo governo, pois além das medidas restritivas da política econômica, o cenário econômico internacional piorou muito ao longo desse ano e a tendência continuou nos anos seguintes. Para estimular a economia, a Selic iniciou uma trajetória de queda no $2^{\circ}$ semestre de 2011 que foi até março de 2013 chegando a 7,25\% a.a. entre outubro de 2012 e abril de 2013. O governo também reduziu o Imposto sobre Operações de Crédito, Câmbio e Seguros (IOF) sobre o crédito pessoal e aumentou, via redução de depósitos compulsórios dos bancos, a liquidez do sistema financeiro. Somaram-se a essas medidas o aumento do valor do salário mínimo, dos subsídios à construção habitacional dentro do programa MCMV para estimular o investimento, uma série de desonerações tributárias ${ }^{11}$, bem como o reajuste nos benefícios do Bolsa Família e o aumento no gasto federal com educação (RELATÓRIO ANUAL BANCO CENTRAL DO BRASIL, 2012).

Novamente os resultados não tiveram os efeitos esperados. Apesar das políticas expansionistas acima descritas, o crescimento do PIB brasileiro desacelerou, com a retração

\footnotetext{
${ }^{11}$ Pressionado por entidades representativas do empresariado brasileiro que argumentam que o custo do trabalho no país é muito alto, tornando cara a produção e impedindo a concorrência com os produtos de outros países, o que desestimularia os empresários a admitirem trabalhadores com vínculos formais, o governo federal adotou medidas para a desoneração tributária de alguns setores da economia. Para a desoneração da folha de pagamentos, modificou-se a forma de contribuição do empresariado à Previdência Social, passando de uma taxa de $20 \%$ sobre o total pago nas folhas de salários para uma taxa de $1 \%$ ou $2 \%$, a depender do setor, sobre a receita bruta obtida no mês. Em 2011, quando o Plano Brasil Maior foi instituído, a desoneração da folha era uma medida temporária concedida a quatro setores: confecções, produção de calçados, móveis e software. Aumentada anualmente, em 2015 já beneficiava 56 setores da economia, e passou a ser permanente, na forma da Lei 13.043. Também foram instituídas outras medidas como a redução do Imposto de Renda das empresas; a redução do Imposto sobre Produto Industrializado (IPI) para bens de investimento e de consumo; a devolução, aos empresários de setores exportadores, do valor pago em impostos como o Programa de Integração Social (PIS) e a Contribuição para o Financiamento da Seguridade Social (Cofins); criação do Regime Especial de Reintegração de Valores Tributários para as Empresas Exportadoras - Reintegra); e outras. Com essas desonerações esperavase resultados positivos para a competitividade da indústria, para o crescimento econômico e para o emprego formal no país, o que não ocorreu, como revelam os Relatórios do Bacen.
} 
do investimento e a queda no crescimento do consumo. A inflação, no entanto, permaneceu elevada, pressionada pela combinação de choques desfavoráveis em alguns preços agrícolas com aumento dos preços dos serviços (BARBOSA, 2013).

Diante desse quadro, o ano de 2013 foi um ponto de inflexão na conjuntura brasileira. Diversos segmentos sociais foram às ruas nas chamadas Jornadas de Junho, em várias manifestações populares por todo o país que inicialmente surgiram para contestar os aumentos nas tarifas de transporte público, mas que logo também se tornaram protestos contra a violência policial e outros temas, como os gastos públicos em grandes eventos esportivos internacionais, a má qualidade dos serviços públicos, além da corrupção política. Nesse mesmo ano, alguns sinais de piora da situação econômica e política do país começam a ficar mais claros. $\mathrm{O}$ ambiente internacional não era muito favorável para a economia brasileira ${ }^{12}$, as contas públicas não apresentavam tendências de melhora e as receitas públicas estavam estagnadas em 16,6\% do PIB. Ao invés de redirecionar o modelo econômico, o governo Dilma adotou medidas conjunturais e elevou as despesas, notadamente as de custeio (de 6,3\% em 2012, para 6,8\% em 2013 e 7,4\% em 2014), não reconhecendo em tempo hábil a piora da situação econômica que desembocou na deterioração das contas públicas brasileiras.

Passadas as eleições de 2014, o governo federal anunciou medidas para conter esse quadro negativo, tentando um ajuste fiscal que impactou fortemente o crescimento econômico e o emprego no país. As renúncias fiscais e de reduções de impostos que marcaram a gestão novo desenvolvimentista de Lula e Dilma não puderam mais ser mantidas e o esforço passou a ser o de reduzir os gastos e aumentar as receitas ${ }^{13}$. Porém, o crescimento econômico fícou em patamares muito baixos $(2,49 \%$ em 2013 e 0,1\% em 2014) e as contas públicas pioraram sobremaneira $^{14}$.

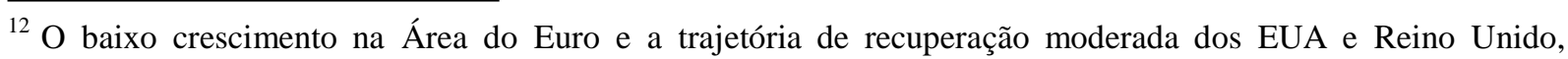
somadas ao crescimento chinês aquém do previsto, fizeram com que as cotações internacionais das commodities agrícolas e metálicas continuassem a cair em 2013 e prejudicassem o desempenho das economias emergentes.

${ }^{13}$ As renúncias e reduções de impostos foram substituídas por um "realismo tarifário", com propostas de criação de novos tributos e o retorno da Contribuição Provisória sobre as Movimentações Financeiras (CPMF). As Medidas Provisórias (MPs) 664 e 665, alteraram as regras de benefícios como o Auxílio-Doença, Pensão por Morte, Abono Salarial, Seguro-Desemprego tentando conter a expansão dos gastos com custeio, que saltaram de $5,9 \%$ para $7,4 \%$ entre 2011 e 2014. As despesas com o abono salarial e o seguro-desemprego haviam saído de $0,24 \%$ para $0,98 \%$ do PIB no mesmo período. Houve redução do gasto em diversos programas como o PAC mobilidade e saneamento, MCMV, Programa Nacional de Acesso ao Ensino Técnico e Emprego (PRONATEC), Fundo de Financiamento Estudantil (FIES) e Ciência sem Fronteira, com redução de metas e alongamento de prazos de execução, além de o adiamento dos reajustes dos servidores públicos, suspensão de concursos públicos, e redução de outros itens de custeio para equacionar os problemas das contas públicas.

${ }^{14}$ Houve redução do superávit primário (de 2,23\% em 2012 para 1,77\% em 2013 e -0,59\% do PIB em 2014), aumento dos juros nominais (4,54 em 2012, 4,83\% em 2013 e 5,64\% do PIB em 2014) e das necessidades de financiamento do setor público, que saltaram de 2,31 em 2012 para 6,23\% do PIB em 2014, atestam os Relatórios Anuais do Bacen.
} 
A promoção do desenvolvimento econômico com inclusão social que buscou instrumentos de fortalecimento do crédito revelou suas fragilidades e trouxe novos desafios e dificuldades. Dados da Serasa Experian mostram que em agosto de 2014 o número de inadimplentes atingira o recorde de 57 milhões de pessoas, o que, considerando o total da população brasileira com 18 anos ou mais (144 milhões de pessoas), implicava em cerca de $40 \%$ inadimplentes. Esse total de consumidores com dívidas em atraso era superior ao verificado em agosto de 2013 (55 milhões) e no mesmo mês de 2012 (52 milhões de pessoas).

Assim, a estratégia de crescimento apoiada no mercado interno, cujo ápice foi em 2010 quando o consumo das famílias representou 4,24\% do PIB, parece ter-se esgotado. As análises nessa seção evidenciam que a proposta novo desenvolvimentista de crescimento econômico com política distributiva não tem conseguido se financiar. O contínuo e expressivo ingresso de novos consumidores nas classes de renda de maior poder aquisitivo resultante dessa política teve como efeito positivo a mudança na estrutura social brasileira, com 32 milhões de consumidores das classes D/E subindo para a classe C entre 2003 e 2011, que passou a representar mais da metade da população (54\%) (SANTOS, 2014). Porém, em 2012 os dados do Índice de Expectativas das Famílias do IPEA mostrava que 9,1\% das famílias brasileiras estavam endividadas, quadro que piorava nas de menor rendimento: 13,5\% das famílias com rendimento até 1 salário mínimo estavam endividadas. A Pesquisa de Endividamento e Inadimplência do Consumidor (PEIC) da Confederação Nacional do Comércio de Bens, Serviços e Turismo (CNC) mostrava que o endividamento atingia quase 90\% das famílias brasileiras naquele ano, sendo mais de $20 \%$ com contas em atraso e 7,8\% declaravam não ter condições de pagar. É crescente o número de número de pessoas que procura o Programa de Apoio ao Superendividado (PAS) dos Procons, que em São Paulo teve 1.691 pessoas atendidas em 2014.

\section{O direito do consumidor e o superendividamento no Brasil: perspectivas factíveis de prevenção e tratamento?}

Diante do quadro acima exposto acerca do novo desenvolvimentismo enquanto política econômica e o superendividamento por ela favorecido é que se impõe a necessidade de estudo e análise do possível tratamento jurídico de uma categoria de consumidores superendividados no Brasil, cabendo também investigar como o ordenamento pátrio tem trabalhado o tema na esfera consumerista. Há algo a ser trabalhado neste sentido? Como a lei 
brasileira se porta diante do tema do superendividamento? São questionamentos como esses que o presente título tenta responder.

O endividamento é um fato individual, mas com consequências sociais e sistêmicas, cada vez mais claras. A economia de mercado, liberal, adotada pelo Brasil, é por natureza uma economia de endividamento mais do que uma economia de poupança (MARQUES, 2010). O novo desenvolvimentismo alargou sobremaneira o mercado de crédito no país e a combinação de aumento do poder de compra da população com medidas de política econômica de um modelo de crescimento que teve no consumo uma variável chave favoreceu o superendividamento de um grande contingente de brasileiros.

A oferta do crédito ao consumidor deveria ser alicerçada a partir de aspectos claros, precisos e objetivos que consagrassem uma espécie de consumo consciente, pautada em uma política de juros menos agressiva, com critérios de concessão melhor definidos e previamente elaborados, bem como a contínua conscientização dos consumidores sobre a necessidade de um consumo equilibrado. O atual nível de superenvidamento da sociedade brasileira acarreta efeitos desastrosos não somente no âmbito das relações de consumo, como também nas relações familiares, aumento de doenças, danos psicológicos, perturbações nas relações familiares e outros, o que não pode ser desconsiderado pelo legislador, argumenta Benjamin (2014). Ademais, Soares (2013) adverte que o excessivo endividamento impõe sérios problemas econômicos, em termos de perda de produtividade de segmentos da população que, sob o fardo do débito, tem ceifado sua liberdade e debilitado sua capacidade produtiva.

No Brasil, o legislador constituinte destacou o consumidor como um efetivo portador de direitos, assegurando-lhe na Carta de 1988, posição nos "Direitos e Garantias Fundamentais" (artigo $5^{\circ}$, inciso XXXII), conferindo-lhe "cidadania", e contemplando sua defesa como “princípio", no Título "Da Ordem Econômica e Financeira" (art. 170, V) (SOUZA, 2002). Porém, não se tem compreendido aqui no Brasil, a significação que certos mandamentos constitucionais deveriam ter, mal que atinge, em maior ou menor grau, os três Poderes da República (DE LUCCA, 2003).

Ainda assim, o Código de Defesa do Consumidor (CDC) trouxe uma nova concepção contratual que está essencialmente estruturada sobre os princípios da equidade e de boa-fé. Cavalieri Filho (2008) adverte que a afronta a estes princípios rompe o desejado e justo equilíbrio econômico da relação jurídica de consumo, fazendo ruir o Direito e passa a representar uma vantagem excessiva para o fornecedor e um ônus não razoável para o consumidor, pelo que se torna imprescindível a atuação do Estado, na defesa do sujeito 
vulnerável, com o objetivo de harmonizá-la e equilibrá-la, inclusive porque o próprio modelo novo desenvolvimentista favoreceu amplamente a tomada de crédito, como as seções anteriores mostraram.

Faz-se necessário, então, uma análise crítica do Projeto de Lei no 283/2012 de autoria do Senador Jose Sarney que pretende reformar o Código Brasileiro de Defesa do Consumidor (CDC) para aperfeiçoar a disciplina do crédito ao consumidor e dispor sobre a prevenção do superendividamento. Atualmente enviado à Câmara dos Deputados, tal Projeto de Lei revela uma nítida preocupação do legislativo em conceder tratamento jurídico específico às situações de superendividamento, fomentando a proteção consumerista já existente no CDC e ainda oportunizando uma perspectiva viável no tratamento do consumidor superendividado.

De um modo geral, o panorama traçado pelo PL 283/2012 perpassa pelos momentos précontratual, contratual e pós-contratual, estabelecendo desde logo no artigo $5^{\circ}$, inciso VI, que dispõe sobre os instrumentos de execução da Política Nacional das Relações de Consumo, a instituição de mecanismos de prevenção e tratamento extrajudicial e judicial do superendividamento e de proteção do consumidor pessoa física, visando garantir o mínimo existencial e a dignidade humana.

Outrora no artigo $6^{\circ}$, inciso XI, estabelece como direito básico do consumidor a garantia de práticas de crédito responsável, de educação financeira, de prevenção e tratamento das situações de superendividamento, preservando o mínimo existencial, por meio da revisão e repactuação da dívida, entre outros.

Ambos os incisos citados acima são importantes para constatar duas observações importantes sobre a matéria: primeiramente, a reforma objetiva atingir uma categoria própria de consumidores superendividados, pessoas físicas, e, tal restrição é feita de maneira acertada, posto que, apesar da pessoa jurídica poder figurar como consumidora numa relação jurídica de consumo, já que se adotou no Brasil, consoante a jurisprudência pacificada no âmbito do Superior Tribunal de Justiça (STJ), a teoria finalista mitigada/aprofundada/atenuada ${ }^{15}$, as pessoas jurídicas contam com institutos próprios do direito empresarial nos casos de dificuldade financeira, dentre os quais citamos a recuperação judicial e extrajudicial e a falência.

\footnotetext{
${ }^{15}$ A Teoria Finalista Mitigada, consolidada no âmbito do Superior Tribunal de Justiça (STJ), aprofunda o conceito de consumidor investigando se pessoas jurídicas podem ser consumidoras para fins de aplicação do Código de Defesa do Consumidor. A jurisprudência já assentou entendimento de que estas pessoas poderão figurar como consumidoras numa relação jurídica de consumo, independentemente se a aquisição do produto ou do serviço vir a integrar a cadeia produtiva da pessoa jurídica. Para tanto, deverá ser provada a vulnerabilidade da pessoa jurídica, seja ela no aspecto técnico, jurídico, econômico ou informacional.
} 
Ademais, reconhecer a prevenção e tratamento do superendividamento do consumidor pessoa física como direito básico, vide o já citado artigo 6, inciso XI, é alicerçar o terreno e a base fundamental para qualquer discussão acerca de como o crédito é oferecido ou restringido e até mesmo de como o Estado poderá intervir nessas relações contratuais para a garantia desses direitos.

Portanto, a consagração por si só de mais este direito básico do consumidor já pode ser considerado um avanço qualitativo rumo a tutela da matéria do superendividamento, lançando as bases e as diretrizes sobre as quais será dado o tratamento jurídico da questão.

Objetivamente, a modificação de maior destaque ficará a cargo da Seção IV do CDC, que pelo PL 283/2012, ocorreria a criação de sete artigos, compreendidos entre o artigo 54-A até o 54-G que disporiam sobre a prevenção do superendividamento e ainda do artigo 104-A que regulamentaria o processo de conciliação.

De modo geral, os artigos 54-A ao 54-D exteriorizam uma preocupação muito clara com um dos princípios corolários do CDC que é o princípio da informação. Por isso mesmo, a prevenção ao superendividamento está sedimentada no PL 283/2012, sobre o aspecto da informação prévia ao consumidor, do crédito responsável, da sua educação financeira, do consumo consciente de modo que o mesmo não seja excluído do mercado de consumo em detrimento de suas dificuldades financeiras.

O artigo 54-C, inciso I, é bastante claro com esta perspectiva, já que impõe de maneira cogente ao fornecedor de crédito, previamente à contratação, a conduta de esclarecer, aconselhar e advertir adequadamente o consumidor sobre a natureza e a modalidade do crédito oferecido, assim como sobre as consequências genéricas e específicas do inadimplemento.

Porém, a grande inovação pode ser destacada como a possibilidade da conciliação no superendividamento, prevista no já citado artigo 104-A, do PL 283/2012, quando a requerimento do consumidor superendividado pessoa física, o juiz poderá determinar a instauração de processo de repactuação de dívidas, visando a realização de audiência conciliatória, com a presença de todos os credores na qual o consumidor apresentará proposta de plano de pagamento com prazo máximo de 5 (cinco) anos.

Importante registrar ainda, a grande importância do parágrafo $1^{\circ}$ deste artigo, uma vez que ele traz uma definição objetiva do que é o superendividamento do consumidor pessoa física, entendido como aquele em que há o comprometimento de mais de trinta por cento da renda líquida do consumidor com o conjunto de suas dívidas não profissionais, exigíveis e 
vincendas, excluído o financiamento para aquisição da casa própria e desde que inexistentes bens livres e suficientes para liquidação total do passivo.

Contudo, não parecem viáveis as duas restrições impostas pelo artigo.

A primeira relaciona-se ao termo "dívidas não profissionais", uma vez que ele é abrangente e dotado de indeterminabilidade, o que pode dar margem a interpretações equivocadas sobre o real alcance do dispositivo legal. Ademais, o enfoque de aplicação das normas sobre prevenção e tratamento do superenvididamento como já narrado, somente alcançará consumidor pessoa física, motivo pelo qual a distinção entre dívidas profissionais e não profissionais parece-nos inócua.

A segunda é com relação à exclusão das dívidas concernentes a financiamento imobiliário para aquisição da casa própria pelo consumidor, posto que o comprometimento da renda dos consumidores é real com relação a esta parcela e, muitas vezes, correspondem a uma grande porcentagem da renda líquida dos consumidores, motivo pelo qual também deveria estar inserida no âmbito de proteção que o PL 283/2012 prescreve.

Sobre o artigo 104-A e incisos, expõe Lima (2014. p. 138):

A previsão é, sem dúvida, uma conquista já que por razões econômicas e culturais, o superendividamento do consumidor sempre foi tratado sob uma perspectiva individual. De acordo com a previsão mencionada, o consumidor passa a ter o direito de ver sua situação de superendividamento analisada globalmente pelo Poder Judiciário que até então se limitava a revisar individualmente os contratos de crédito. Vale destacar que o tratamento global da situação econômica do devedor é uma abordagem comum a todos os procedimentos de superendividamento do consumidor existentes no direito comparado que recebem diferentes denominações, em alguns países são chamados de "falência", "insolvência", "procedimento de ajustamento das dívidas de consumo" ou "regramento coletivo de dívidas".

Segundo Benjamin (2014) novos instrumentos e técnicas de proteção foram incluídos no projeto de lei $\mathrm{n}^{\circ} 283 / 2012$, visando, primeiramente, prevenir o superendividamento da pessoa física de boa-fé com ampla inspiração na legislação de direito comparado, especialmente a europeia.

O que se percebe é que o tema do superendividamento no Brasil nunca recebeu o devido tratamento jurídico-normativo e também econômico, tanto que a maioria dos conflitos advindos de relações contratuais envolvendo concessão de crédito ao consumidor são resolvidas pelo Poder Judiciário em ações revisionais, por exemplo, não havendo mecanismos efetivos à disposição do consumidor para resolução extrajudicial ou conciliatória do impasse, motivo pelo qual o PL 283/2012 é extremamente necessário em terrae brasilis para tutelar essas relações jurídicas de consumo. 
Entretanto, como comentado alhures, esse problema tem se mostrado, durante a última década, um verdadeiro desafio para as instituições democráticas e para o próprio ambiente mercantil, o que tem sido, desde então, objeto de estudo de alguns juristas brasileiros que ousaram dar destaque e a devida atenção às vicissitudes apresentadas.

Outra experiência exitosa rumo à prevenção e tratamento do superendividamento no Brasil é o Observatório do Crédito e Superendividamento do Consumidor (OCSC) da Universidade Federal do Rio Grande do Sul (UFRGS), coordenado por Cláudia Lima Marques, Káren Rick Danilevicz Bertoncello e Clarissa Costa de Lima, cujo objetivo é investigar os principais problemas na concessão do crédito, estimular trocas de experiências e a integração de políticas públicas e ações de prevenção e tratamento do consumidor superendividado, promovendo ainda estudos de Direito Comparado a propósito do tema com o apoio do Ministério da Justiça/DPDC.

Importa registrar ainda a criação do projeto piloto de tratamento do consumidor superendividado, inédito no país, em parceria firmada com o Tribunal de Justiça do Rio Grande do Sul (TJ/RS), cuja sistemática de funcionamento é definida da seguinte forma:

O acordo entre o credor e o consumidor, em audiência, é considerado um título judicial. Essa sentença/título apresenta várias vantagens: para o fornecedor, poupa o processo de conhecimento e permite recuperar dívidas muitas vezes consideradas já perdidas pelos fornecedores (geralmente o acordo prevê o pagamento, em primeiro lugar, das dívidas pequenas, deixando as maiores e o próprio consignado para depois); e para o consumidor de boafé, permite, já no primeiro pagamento a qualquer dos credores, a retirada do seu nome do SPC (e outros bancos de dados negativos) e mantém plena sua dignidade (e de sua família) (MARQUES, 2010, P. 34).

O que o projeto de lei desafia é a criação de um modelo de falência adequado à realidade brasileira, considerando a heterogeneidade de seus consumidores, ou seja, que possa ser útil a consumidores de distintas classes sociais, sem olvidar aqueles desfavorecidos, sem bens e sem renda, conhecidos no direito comparado como NINA (no income, no assets) (MARQUES, 2010). No mesmo caminho do TJ/RS é que se implementou no Tribunal de Justiça do Distrito Federal e Territórios, o programa "Superendividados", por meio do Centro Judiciário de Solução de Conflitos e de Cidadania (CEJUSC/Super), criado com a finalidade de promover o tratamento e a resolução de conflitos envolvendo consumidores em situação de superendividamento, constituindo unidade judiciária, com autonomia e estruturas próprias, criadas a partir do Programa de Prevenção e Tratamento dos Consumidores Superendividados que residem no Distrito Federal. 
A sistemática deste programa se organiza a partir da provocação direta por parte do consumidor interessado que deverá enviar pedido de inscrição por e-mail ao órgão responsável, o qual deverá comparecer posteriormente ao Tribunal para participação em entrevista e apresentação de documentação necessária, participação em oficina sobre educação financeira do consumidor, sessões de orientação individual, no âmbito financeiro ou psicossocial e ainda sessão de conciliação para renegociação de dívidas.

$\mathrm{O}$ que se percebe é que o Brasil tem caminhado rumo a uma tutela específica do consumidor pessoa física em casos de superendividamento, inclusive com a atuação dos Tribunais da Federação com projetos direcionados a esse objetivo, como citado acima, no caso dos Tribunais dos Estados do Rio Grande do Sul e Distrito Federal e Territórios, ainda que ausente no ordenamento jurídico brasileiro uma norma jurídica voltada para este tema, o que denota a preocupação do poder judiciário com o vertiginoso aumento de consumidores brasileiros superendividados.

O projeto de lei $n^{\circ}$ 283/2012 revela também a preocupação do legislativo em estabelecer uma tutela jurídica totalmente voltada para a prevenção e tratamento do superendividamento e o faz com grande influência do direito comparado, como por exemplo, o direito francês que prevê como instrumento de tratamento a preferência pelos planos de pagamento.

O plano de pagamentos, associado aos países de tradição civil law, pode ser acordado consensualmente pelas partes ou imposto pelo juiz. Trata-se de uma alternativa possível para solucionar o endividamento por meio de uma programação na qual o devedor efetuará pagamento aos credores durante determinado período. Como resultado, o devedor tem que trabalhar para reembolsar as dívidas pretéritas ficando submetido a uma disciplina rigorosa no que tange aos seus gastos pessoais e de subsistência (LIMA, 2014, p. 154).

Porém, a despeito das inovações trazidas com o projeto de lei $n^{\circ} 283$, acentua-se a necessidade também do perdão de dívidas nos casos de consumidores sem bens e sem renda, tal qual prescreve o direito norte americano. O perdão de dívidas presente nos países de tradição common law que seguem a filosofia do fresh start, restaura a situação financeira do devedor num curto período de tempo mediante a liquidação dos bens livres e penhoráveis. No caso de inexistência de bens, o devedor fica liberado do pagamento de dívidas pretéritas. Parte-se da premissa de que se o devedor trabalha somente para pagar seus credores, ele não terá nenhum incentivo para trabalhar mais e ainda terá seu futuro sem esperança e comprometido com o pagamento de dívidas (LIMA, 2014). 
Assim caminha e de maneira acertada, a sugestão do Instituto Brasileiro de Política e Direito do Consumidor (BRASILCON) para inclusão no PL nº 283/2012 do artigo 104-B, que disporia o seguinte:

Art. 104-B. Inexitosa a conciliação com um ou mais credores, ou ausente algum deles, o juiz procederá a citação de todos os credores cujos créditos não integram o acordo celebrado, instaurando o processo de superendividamento. Serão considerados, se for o caso, os documentos e as informações prestadas em audiência. No prazo de 5 dias os credores citados juntarão documentos e as razões da negativa de renegociar. Em seguida, o juiz julgará apresentado o plano judicial com preservação do mínimo existencial.

$\S 1^{\circ}$ O juiz poderá nomear administrador, preferencialmente dentre as entidades integrantes do Sistema Nacional de Defesa do Consumidor, previstas no artigo 82 do Código de Defesa do Consumidor. O administrador apresentará plano de pagamento, no prazo de 10 dias, contemplando medidas de temporização ou atenuação dos encargos.

$\S 2^{\circ}$ Aplicam-se ao procedimento judicial de superendividamento as disposições contidas nos $\S 4^{\circ}$ e $\S 5^{\circ}$ do artigo 104-A, no que couber (INSTITUTO BRASILEIRO DE POLÍTICA E DIREITO DO CONSUMIDOR BRASILCON, 2016, p. 5-6) .

Lima (2014, p. 174-175) complementa a necessidade de inclusão de outros três parágrafos no artigo 104-B, com a qual também os autores desse artigo concordam, nos seguintes termos:

$\S 3^{\circ}$ Nos casos em que se constatar que o devedor não tem bens disponíveis nem renda que exceda o mínimo existencial para o pagamento dos credores, o juiz poderá declarar a remissão das dívidas remanescentes mediante condições que poderão ser exigidas do devedor, isolada ou cumulativamente:

a) não ocultar ou dissimular os rendimentos que receba a qualquer título, devendo apresentar relatórios sobre seus esforços de recuperação financeira sempre que for requisitado;

b) exercer uma profissão remunerada, não a abandonando sem motivo legítimo, e a procurar diligentemente tal profissão quando desempregado, não recusando justificadamente algum emprego para o qual seja apto;

c) informar ao juiz e o administrador de qualquer mudança de domicílio ou de condições de emprego, no prazo de 10 dias após a respectiva ocorrência;

d) entregar ao administrador, a parte dos rendimentos disponíveis, quando houver, para rateio entre os credores;

e) não fazer quaisquer pagamentos diretamente aos credores a não ser por meio do administrador e não criar qualquer vantagem especial para algum desses credores;

f) frequentar curso de educação financeira ou similar;

$\S 4^{\circ} \mathrm{O}$ juiz fixará o prazo de cumprimento das condições, que não poderá ceder a dois anos, tendo em consideração, especialmente, as características pessoais do devedor, o grau de superendividamento, bem como os motivos que o levaram ao superendividamento; 
$\S 5^{\circ} \mathrm{O}$ juiz poderá declarar a remissão imediata das dívidas quando verificar que o crédito foi concedido de forma irresponsável ou sem a observância dos deveres de informação e conselho pelo fornecedor;

$\S 6^{\circ}$ A remissão de dívidas não abrange as dívidas alimentícias, as indenizações devidas por atos ilícitos praticados pelo devedor, as multas administrativas, sanções criminais e os créditos tributários".

A ratificação do modelo o francês (plano de pagamentos) e o norte americano (perdão de dívidas), sob uma perspectiva de convergência mostra-se salutar para a prevenção e tratamento do superendividamento no Brasil, já que nem sempre a opção do plano de pagamentos poderá ser exequível, restando clara a necessidade de utilização do modelo francês em determinados concretos. Essa perspectiva certamente é factível e deverá ser integrada ao PL $\mathrm{n}^{\circ}$ 283/2012, para que o arcabouço jurídico existente seja aperfeiçoado tornando-se modo mais claro, preciso, objetivo e completo na tutela dos direitos dos consumidores pessoas físicas em situação de superendividamento.

\section{Considerações Finais}

O novo desenvolvimentismo, notadamente marcado por uma política econômica de estímulo aos índices de crescimento e com viés distributivo, engendrou a criação de políticas voltadas ao expansionismo do mercado interno e à intensa intervenção do Estado como instrumento hábil a reduzir a desigualdade no que tange a distribuição de renda, constituindo assim uma nova roupagem da estrutura econômica brasileira no início dos anos 2000 .

Ademais, essa estrutura concebida e aliada a outras medidas de política econômica, que ampliaram o mercado de crédito no país, favoreceu, a seu modo, a inclusão social e econômica de milhões de brasileiros, o que veio ser interrompido com os novos desafios e dificuldades, notadamente pelo gradual e crescente aumento do número de endividados no Brasil nos últimos anos.

A constatação do superendividamento e a busca de alternativas viáveis para sua prevenção e tratamento deverão ser uma preocupação e da economia e do direito no século XXI no Brasil, no qual, grande parte da sociedade, segundo dados acima colacionados, encontra-se superendividada, urgindo haver uma tutela jurídica satisfatória e eficaz com fulcro na prevenção e tratamento do consumidor de crédito em situação de endividamento severo. A aposta lançada com o Projeto de Lei $n^{\circ}$ 283/2012 certamente vai ao encontro desta preocupação e concretiza-se como verdadeiro marco, já que diferentemente de outros países no mundo, como França e Estados Unidos, no Brasil não existe, até o presente momento, uma 
tutela jurídica específica para o superendividamento como se quer constituir através do projeto de lei mencionado.

Sem dúvida, a estruturação de um microssistema jurídico voltado não somente a prevenir, como também estabelecer as bases e diretrizes para o tratamento dos consumidores em situação de superenvidamento, exterioriza uma necessidade que há muito tempo vem sendo preterida no Brasil e até mesmo ignorada. A incorporação das medidas narradas no item anterior ao PL 283/2012 é uma condição inexorável para que a tutela do superendividamento seja integralmente satisfeita no Brasil, sendo relevante, portanto, a concepção de um modelo misto no Brasil, no qual, mesmo que a regra seja a preferência pelos planos de pagamento, seja viável também a corporificação do perdão de dívidas (fresh start) para os consumidores de baixa renda e sem bens disponíveis, de modo a possibilitar a garantia do mínimo existencial tal qual propõe Lima (2014).

\section{Referências}

ANNIBAL, Clodoaldo. LUNDBERG, Eduardo. KOYAMA, Sérgio Mikio. Crise de 2008 e as Mudanças no Mercado de Crédito. In BANCO CENTRAL DO BRASIL. Relatório de Economia Bancária e Crédito. Brasília: 2009, p. 37-52.

BANCO CENTRAL DO BRASIL. Boletim - Relatório Anual. Brasília: vários anos (2008, 2009, 2010, 2011, 2012, 2013, 2014).

BANCO CENTRAL DO BRASIL. Relatório de Economia Bancária e Crédito. Brasília: vários anos (2009, 2010, 2011, 2012, 2013, 2014).

BARBOSA, Nelson. Dez anos de política econômica. In: SADER, Emir. 10 anos de governos pós-neoliberais no Brasil: Lula e Dilma. São Paulo: Boitempo; Rio de Janeiro: FLACSO Brasil, 2013, p. 69-102.

BATISTA, Paulo Nogueira. O Consenso de Washington. A visão neoliberal dos problemas latino-americanos. 1994. Disponível em: http://www.usp.br/fau/cursos/ graduacao/ arq_urbanismo/disciplinas/aup0270/4dossie/nogueira94/nog94-cons-washn.pdf. Acesso em 04 de março de 2016.

BELUZZO, Luiz Gonzaga. Os anos do povo. IN: SADER, Emir. 10 anos de governos pósneoliberais no Brasil: Lula e Dilma. São Paulo: Boitempo; Rio de Janeiro: FLACSO Brasil, 2013, p. 103-110. Disponível em http://www.flacso.org.br/ dez_anos_governos_ pos_neoliberais/archivos/ 10_ANOS_GOVERNOS.pdf. Acesso em 13 de maio de 2015.

BENJAMIN, Antônio Herman. O Tratamento do Superendividamento e o Direito de Recomeçar dos Consumidores, de Clarisse Costa de Lima. In: Revista de Direito do Consumidor. n. 92. São Paulo: Revista dos Tribunais, Março/Abril 2014. 
BENJAMIN, Antônio Herman. O Tratamento do Superendividamento e o Direito de Recomeçar dos Consumidores, de Clarisse Costa de Lima. In: Revista de Direito do Consumidor. n. 92. São Paulo: Revista dos Tribunais, Março/Abril 2014.

BRESSER-PEREIRA, Luiz Carlos. O novo desenvolvimentismo e a ortodoxia convencional. São Paulo em Perspectiva, vol. 20, No 3, p. 5-24, julho-setembro 2006.

CAVAlieri FILHO, Sérgio. Programa de Direito do Consumidor. São Paulo: Atlas, 2008.

DE LUCCA, Newton. Direito do Consumidor. São Paulo: Quartier Latin, 2003.

INSTITUTO BRASILEIRO DE POLÍTICA E DIREITO DO CONSUMIDOR (BRASILCON). Manifestação BRASILCON ao Projeto de Lei $\mathbf{n}^{\mathbf{0}} \mathbf{2 8 3} / \mathbf{2 0 1 2}$. Disponível em: http://www.senado.leg.br/atividade/materia/get PDF.asp?t=121284\&tp=1. Acesso em: 06.03.2016.

LIMA, Clarissa Costa de. O Tratamento do Superendividamento e o Direito de Recomeçar dos Consumidores. São Paulo: Revista dos Tribunais, 2014.

MARQUES, Cláudia Lima. Algumas Perguntas e Respostas sobre a Prevenção e Tratamento do Superendividamento dos Consumidores Pessoas Físicas. In: Revista de Direito do Consumidor. n. 75. São Paulo: Revista dos Tribunais, Julho/Setembro 2010.

MORAIS, Lecio; SAAD FILHO, Alfredo. Da economia política à política econômica: o novodesenvolvimentismo e o governo Lula. Revista de Economia Política, , vol. 31, no. 4, p. 507527, 2011.

REYMÃO, Ana Elizabeth. MIRANDA, Tássia Baia. Estado e competitividade da indústria brasileira na política econômica novo desenvolvimentista. In: VIII CONGRESSO DE DIREITO E ECONOMIA, Porto Alegre, 2014. Anais. Porto Alegre: Instituto de Direito e Economia do Rio Grande do Sul.

REYMÃO, Ana Elizabeth. Novo desenvolvimentismo, competitividade da indústria brasileira e o princípio da busca do pleno emprego. In: LARA, Fabiano Teodoro de Rezende. FERREIRA, Gustavo Assed. VIEIRA, Susana Camargo. Direito, economia e desenvolvimento sustentável I. Florianópolis: CONPEDI, 2015, p. 443-473. Disponível em http://www.conpedi.org.br/publicacoes/66fsl345/ki9ipk3k/ b64V6cF2C6LbbsyW.pdf. Acesso em 25 de janeiro de 2016.

SADER, Emir. A construção da hegemonia pós-neoliberal. In SADER, Emir (org). 10 anos de governos pós-neoliberais no Brasil: Lula e Dilma. São Paulo, SP: Boitempo; Rio de Janeiro: FLACSO Brasil, 2013, p. 135-143. Disponível em http://www.flacso.org.br/dez_anos_governos_pos_neoliberais/archivos/10_ANOS_GOVERN OS.pdf. Acesso em 13 de maio de 2015.

SANTOS, Carlos Alberto dos. O microcrédito e a formalização de micronegócios: desafios e perspectivas no Brasil. IN A atividade e a política de microcrédito no Brasil: Visões sobre sua evolução e futuros desafios. Fortaleza: Instituto de Desenvolvimento do Trabalho e Universidade de São Paulo, 2014, p. 125-139.

SOARES, Ardyllis Alves. (Trad.). Conclusões do Relatório Mundial sobre o Tratamento do Superendividamento e Insolvência da Pessoa Física. In: Revista de Direito do Consumidor. n. 89. São Paulo: Revista dos Tribunais, Setembro/Outubro 2013.

SOUZA, Washington Peluso Albino de. Lições de Direito Econômico. Porto Alegre: Sérgio Antônio Fabris, 2002. 